\title{
EFEKTIVITAS EKSTRAK BIJ PEPAYA (Carica papaya linnaeus) SEBAGAI LARVASIDA PADA LARVA AEDES AEGYPTI INSTAR III
}

\author{
Jelita Mahdalena Isra ${ }^{1)}$
}

\begin{abstract}
Abstrak
Kota Bandar Lampung merupakan daerah endemis DBD. Menurut data Dinas Kesehatan Provinsi Lampung menyebutkan pada tahun 2015, dari 15 Kabupaten/Kota terdapat jumlah penderita DBD mencapai 2.996 jiwa yang meninggal 31 jiwa. Melihat kemungkinan adanya dampak negatif yang ditimbulkan oleh Aedes aegypti tersebut maka perlu dilakukan pengendalian dengan menggunakan insektisida nabati. Penggunaan biji pepaya mampu menjadi alternatif larvasida alami yang aman dan mampu membunuh larva Aedes aegypti karena mengandung saponin, flavonoid, dan alkaloid.

Tujuan dari penelitian ini adalah untuk mengetahui efektivitas ekstrak berbagai jenis biji pepaya (Carica papaya Linnaeus) sebagai larvasida pada larva Aedes aegypti instar III. Jenis penelitian yang digunakan yaitu true experimental dengan rancangan penelitian menggunakan postest control group design. Subyek penelitian yang digunakan dalam penelitian ini adalah larva Aedes aegypti Instar III. Variabel bebas dalam penelitian ini adalah ekstrak biji pepaya dari 3 jenis pepaya yang berbeda (Pepaya Lokal, Pepaya Bangkok dan Pepaya California) dengan dosis sama yang paling efekitif menurut penelitian sebelumnya yaitu $50 \mathrm{ml}$ dan waktu kontak. Variabel terikat dalam penelitian ini adalah larva Aedes aegypti. Variabel pengganggu dalam penelitian ini adalah suhu, jumlah larva, dan volume air.

Penelitian mendapatkan rata-rata kematian larva Aedes aegypti pada ekstrak biji Pepaya Bangkok didapatkan raia-rata kematian sebesar 14.62, pada ckstrak biji Pepaya California didapatkan rata-rata kematian sebesar 18.56, pada ekstrak biji Pepaya Cibinong didapatkan rata-rata kematian sebesar 22.12. Sedangkan untuk rata-rata kematian larva dalam 4 kali pengulangan yaitu pada waktu kontak 1 jam didapatkan rata-rata kematian sebesar 5.50. Pada waktu kontak 4 jam didapatkan rata-rata kematian sebesar 13.94. Pada waktu kontak 8 jam didapatkan rata-rata kematian sebesar 17.12. Pada waktu kontak 12 jam didapatkan rata-rata kematian sebesar 18.75. Menurut uji statistik, jenis biji yang paling efektif adalah biji Pepaya Cibinong di waktu kontak 4 jam.
\end{abstract}

Kata kunci : ekstrak, Pepaya Lokal, larva Aedes aegypti .

${ }^{1)}$ Alumni Program Studi D4 Keschatan Lingkungan Politeknik Kesehatan Tanjungkarang

\section{PENDAHULUAN}

Demam Berdarah Dengue merupakan salah satu masalah kesehatan masyarakat di Indonesia dengan jumlah penderita cenderung meningkat dan penyebarannya semakin luas. Pada tahun 2004-2010 Indonesia termasuk negara dengan endemisitas tertinggi kedua setelah Brazil dengan jumlah 129.435 kasus. Kota Bandar Lampung sendiri merupakan daerah endemis DBD. Menurut data Dinas Kesehatan Provinsi Lampung, pada tahun 2015 terdapat 2.996 kasus dengan 31 kematian.

Sampai saat ini obat dan vaksin untuk pengendalian DBD masih dalam tahap penelitian sehingga untuk menanggulangi $\mathrm{DBD}$ diutamakan dengan memutus rantai penularan melalui pengendalian vektornya. (Shinta; Sukowati, 2013).
Larvasida alami dapat ditemukan dalam tumbuhan yang di dalamnya terkandung senyawa yang berfungsi sebagai larvasida, diantaranya adalah saponin, flavonoid, alkaloid, yang ada pada biji pepaya (Kardinan, 2003).

Penggunaan biji pepaya diharapkan mampu menjadi alternatif larvasida alami yang aman dan mampu membunuh larva Aedes aegypti sebagai upaya mengurangi tingginya angka penyakit DBD di Indonesia. Penelitian Mehidyastuti (2012) menyatakan bahwa ekstrak biji pepaya scbagai larvasida memiliki mortalitas sebesar $66-100 \%$ dengan konsentrasi 2200 ppm. Sedangkan penelitian Martini (2016) menyatakan kematian larva sebesar $100 \%$ pada konsentrasi dosis ekstrak $50 \mathrm{ml}$.

Senyawa kimia yang terkandung biji pepaya berupa alkaloid bekerja sebagai racun kontak, 
racun perut dan racun saraf. Alkaloid dan enzim papain dapat masuk ke dalam tubuh larva melalui dinding tubuh dengan cara osmosis karena kulit atau dinding tubuh bersifat permeable, kemudian alkaloid dan enzim papain menyebar ke seluruh tubuh dan menyerang system saraf sehingga dapat mengganggu aktivitas larva. Saponin bekerja sebagai racun perut, racun kontak, racun pernafasan. Tannin bekerja sebagai racun perut. Senyawa-senyawa tersebut akan saling melengkapi dan mendukung yang berdampak pada peningkatan kadar toksisitas. (Fayzal, 2016)

\section{METODE}

Jenis penelitian true experimental dengan rancangan postest control group design. Postest control group design adalah randomisasi, artinya pengelompokkan anggota-anggota kelompok control dan kelompok eksperimen dilakukan berdasarkan acak atau random (Suryabrata, 2000).

Populasi dalam penelitian ini adalah semua larva yang di kembangkan dari telur dan didapatkan dari Loka Litbang P2B2 Baturaja Sumatera Selatan.Sampel diambil dengan teknik purposive sampling, yaitu metode pemilihan sampel berdasarkan sifat atau ciri-ciri tertentu yang berkaitan dengan karakteristik populasi, yaitu :

1. Pada sampel ini diambil larva instar III dengan pertimbangan alat organ larva sudah lengkap. Berdasarkan morfologi dan penampakannya, setiap instar memiliki ciri masing-masing, yaitu :

a. Larva instar I : Ukuran paling kecil yang memiliki panjang 1-2 $\mathrm{mm}$, sifon belum bewarna hitam, dan badan masih terlihat tembus terhadap cahaya.

b. Larva instar II : Ukuran bertambah besar, yang memiliki panjang $2,5-3,9 \mathrm{~mm}$, sifon masih belum terlihat dengan jelas.

c. Larva instar III : Ukuran lebih besar lagi dengan panjang $5 \mathrm{~mm}$ dan sifon sudah terlihat lebih bewarna gelap dibandingkan dengan warna badan, serta gigi sisir sudah terlihat di segmen abdomen ke-8. d. Larva instar IV : Memiliki panjang 7-8 $\mathrm{mm}$.

2. Larva yang masih sehat dengan cara melihat langsung bahwa larva bergerak aktif.

Sesuai dengan ketentuan WHO tahun 2005 yang berjudul Guidelines For Laboratory And Field Testing Of Mosquito Larvicidies, sampel eksperimen ditentukan sebanyak 25 ekor untuk setiap perlakuan dan dilakukan pengulangan atau replikasi sebanyak 4 kali untuk setiap perlakuan. Sehingga untuk mengetahui jumlah sampel keseluruhan yang digunakan pada uji penelitian adalah dengan mengalikan sampel dengan pengulangan atau replikasi. Maka dibutuhkan 400 ekor larva jika pada penelitian terdapat 4 kelompok, yaitu 1 kelompok control dan 3 kelompok ekstrak dari jenis pepaya yang berbeda dalam 4 kali pengulangan.

Penelitian dilakukan dengan cara membagi larva nyamuk ke dalam 4 kelompok, dimana 1 kelompok sebagai kelompok kontrol dan 3 kelompok sebagai kelompok perlakuan ekstrak jenis pepaya yang berbeda. Setiap kelompok terdiri dari 4 bekker glass, setiap bekker glass berisi larva nyamuk Aedes aegypti sebanyak 25 ekor. Bekker glass pada kelompok yang sama berisi ekstrak biji pepaya yang sama. Ekstrak pepaya didapat dengan menggunakan metode masterasi, yaitu perendaman biji pepaya yang sudah dijemur dengan etanol $70 \%$ selama 5 hari.

\section{HASIL}

\section{Kematian Larva Berdasarkan Jenis Ekstrak dan Waktu Kontak Terhadap}

Pada tabel 1 didapatkan rata-rata kematian larva dalam 4 kali pengulangan. Pada control atau yang tidak diberi ekstrak tidak terdapat kematian, pada ekstrak Bangkok rata-rata kematian sebesar 14.62, pada ekstrak California rata-rata kematian sebesar 18.56 , dan pada ekstrak Cibinong didapatkan rata-rata kematian sebesar 22.12. Hasil tersebut menunjukkan bahwa ekstrak Cibinong memiliki angka ratarata kematian paling tinggi dibanding ckstrak biji pepaya jenis lainnya. 
Tabel 1. Rata-Rata Kematian Larva Aedes aegypti Berdasarkan Jenis Ekstrak Biji Pepaya

\begin{tabular}{lcccc}
\hline \multicolumn{1}{c}{ Variabel } & Rata-Rata & Std. Devisiasi & Minimum & Maximum \\
\hline Jenis ekstrak & & & & \\
Kontrol & 0.00 & 0.000 & 0 & 0 \\
Bangkok & 14.62 & 8.740 & 2 & 25 \\
California & 18.56 & 7.882 & 5 & 25 \\
Cibinong & 22.12 & 5.328 & 10 & 25 \\
Waktu kontak & & & & \\
1 jam & 5,50 & 11,180 & 0 & 17 \\
4 jam & 13,94 & 10,544 & 0 & 25 \\
8 jam & 17,12 & 9,539 & 0 & 25 \\
12 jam & 18,75 & 5,502 & 0 & 25 \\
\hline
\end{tabular}

\section{Kematian Larva Berdasarkan Variasi}

Ekstrak dan Waktu Kontak

Pada Tabel 2 diketahui terdapat perbedaan pengaruh antara setiap waktu kontak terhadap kematian larva Aedes aegypti yang diberi ekstrak biji pepaya Bangkok. Pada Tabel 2 diketahui pula adanya perbedaan antara waktu kontak 1 jam dengan 4 jam atau sebaliknya, 1 jam dengan 8 jam atau sebaliknya, 1 jam dengan 12 jam, atau sebaliknya, 4 jam dengan 8 jam atau sebaliknya, 4 jam dengan 12 jam atau sebaliknya, sedangkan pada waktu kontak 8 jam dengan 12 jam tidak terdapat perbedaan pengaruh terhadap kematian larva Aedes aegypti.

Tabel 2. Analisa Games Howel Perbedaan Pengaruh Waktu Kontak dengan Beberapa Ekstrak Biji Pepaya Terhadap Kematian Larva Aedes aegypti Instar III

\begin{tabular}{llcccc}
\hline Variabel Bebas & \multicolumn{5}{c}{ P (Signifikan) } \\
& \multicolumn{1}{c}{1 jam } & 4 jam & 8 jam & 12 jam \\
\hline Ekstrak Jenis & 1 jam & - & 0.005 & 0.000 & 0.000 \\
Pepaya Bangkok & 4 jam & 0.005 & - & 0.016 & 0.004 \\
& 8 jam & 0.000 & 0.016 & - & 0.003 \\
& 12 jam & 0.000 & 0.004 & 0.003 & - \\
\hline Ekstrak Jenis & 1 jam & - & 0.000 & 0.000 & 0.000 \\
Pepaya California & 4 jam & 0.000 & - & 0.002 & 0.002 \\
& 8 jam & 0.000 & 0.002 & - &. \\
& 12 jam & 0.000 & 0.002 &. & - \\
\hline Ekstrak Jenis & 1 jam & - & 0.015 & 0.015 & 0.015 \\
Pepaya Cibinong & 4 jam & 0.015 & - &. &. \\
& 8 jam & 0.015 & - & - &. \\
& 12 jam & 0.015 & - &. & - \\
\hline
\end{tabular}

Dilakukan uji Games Howel untuk

mengetahui keefektifan waktu kontak terhadap menganalisa kefektifan berbagai macam jenis biji pepaya (Tabel 3). Uji Games Howell untuk

Tabel 3. Uji Games Howel Perbedaan Keefektifan Berbagai Macam Jenis Ekstrak Biji Pepaya Terhadap Kematian Larva

\begin{tabular}{llcccc}
\hline \multicolumn{2}{c}{$\begin{array}{c}\text { Variabel } \\
\text { Bebas }\end{array}$} & \multicolumn{4}{c}{ P (Signifikan) } \\
\cline { 2 - 6 } \multicolumn{2}{c}{ Kontrol } & Bangkok & California & Cibinong \\
\hline Ekstrak Biji & Kontrol & - & 0.000 & 0.000 & 0.000 \\
Pepaya & Bangkok & 0.000 & - & 0.547 & 0.034 \\
& California & 0.000 & 0.547 & - & 0.453 \\
& Cibinong & 0.000 & 0.034 & 0.453 & - \\
\hline
\end{tabular}


Tabel 4. Analisa Games Howel Perbedaan Keefektifan Waktu Kontak Terhadap Kematian Larva Aedes aegypti Instar III

\begin{tabular}{cccccc}
\hline \multicolumn{2}{c}{ Variabel bebas } & \multicolumn{4}{c}{ P (Signifikan) } \\
\cline { 2 - 6 } & & 1 jam & 4 jam & 8 jam & 12 jam \\
\hline Waktu Kontak & 1 jam & - & 0.026 & 0.004 & 0.002 \\
& 4 jam & 0.026 & - & 0.807 & 0.564 \\
& 8 jam & 0.004 & 0.807 & - & 0.974 \\
& $12 \mathrm{jam}$ & 0.002 & 0.564 & 0.974 & - \\
\hline
\end{tabular}

\section{PEMBaHASAN}

\section{Kematian Larva Berdasarkan Jenis Ekstrak dan Waktu Kontak}

Pada tabel 1 didapatkan bahwa ekstrak Cibinong memiliki angka rata-rata kematian paling tinggi dibanding ekstrak biji pepaya jenis lainnya. Sehingga ekstrak biji pepaya Cibinong menjadi yang paling efektif selama pengamatan penelitian dilakukan.

Didapatkan pula data rata-rata kematian larva dalam 4 kali pengulangan yaitu pada waktu kontak 1 jam didapatkan rata-rata kematian sebesar 5.50. Pada waktu kontak 4 jam didapatkan rata-rata kematian sebesar 13.94. Pada waktu kontak 8 jam didapatkan rata-rata kematian sebesar 17.12 . Pada waktu kontak 12 jam didapatkan rata-rata kematian sebesar 18.75. Hasil tersebut menunjukkan bahwa terjadi peningkatan rata-rata kematian pada larva Aedes aegypti terhadap waktu kontak. Semakin lama waktu kontak larva Aedes aegypti dengan ekstrak biji pepaya maka akan semakin besar jumlah kematian atau ratarata kematian larva Aedes aegypti.

Hal ini disebabkan oleh semakin lamanya durasi pemaparan ekstrak jenis pepaya semakin lama pula larva terpapar saponin, flavonoid dan alkaloid yang ada pada ekstrak biji pepaya yang diberikan pada larva, sehingga menjadi waktu yang efektif untuk meracun perut larva (stomach poisononing), menghambat kerja enzim kolinestrase pada larva dan menggangu pernafasan larva sehingga menyebabkan kematian larva Aedes aegypti instar III.

Pada tabel 1 dan tabel 2 dapat diketehui bahwa penelitian tentang berbagai jenis ekstrak biji pepaya pada larva Aedes aegypti instar III ini menghasilkan data kematian larva yang berbeda-beda pada tiap jenis ekstrak biji pepaya dan pemaparan waktu kontaknya. Hal tersebut dipengaruhi oleh beberapa faktor diantaranya adalah keefektivitasan ekstrak biji pepaya, lamanya waktu kontak pemaparan, dan kesehatan larva.
Kesehatan larva yang tidak dapat diperiksa dapat mempengaruhi jumlah kematian larva Aedes aegypti pada setiap pengulangan. Kecfektifitasan jenis ekstrak biji pepaya juga dapat mempengaruhi hasil yang berbeda terhadap kematian lárva Aedes aegypti instar III.

Lamanya waktu kontak dalam pemaparan juga dapat mempengaruhi hasil yang berbeda terhadap kematian larva Aedes aegypti instar III dikarenakan semakin lama waktu kontak semakin lama pula larva Aedes aegypti terpapar oleh racun dari ekstrak biji yang diberikan.

\section{Kematian Larva Berdasarkan Variasi Ekstrak dan Waktu Kontak}

Pada tabel 2, diketahui bahwa terdapat perbedaan pengaruh antara setiap waktu kontak terhadap kematian larva Aedes aegypti yang diberi ekstrak biji pepaya Bangkok. Hal ini dikarenakan semakin lama pemaparan waktu kontak larva dengan ekstrak biji jenis Pepaya Bangkok, jumlah larva Aedes aegypti yang mati pada setiap pengulangan terus bertambah dan jumlah kematian menjadi $100 \%$ pada waktu kontak 12 jam.

Pada tabel 2 diketahui pula adanya perbedaan antara waktu kontak 1 jam dengan 4 jam atau sebaliknya, 1 jam dengan 8 jam atau sebaliknya, 1 jam dengan 12 jam atau sebaliknya, 4 jam dengan 8 jam atau sebaliknya, 4 jam dengan 12 jam atau sebaliknya, sedangkan pada waktu kontak 8 jam dengan 12 jam tidak terdapat perbedaan pengaruh terhadap kematian larva Aedes aegypti.

Data yang tidak varian antara waktu kontak 8 jam dengan 12 jam pada pemberian ekstrak biji pepaya jenis California disebabkan karena pada waktu kontak 8 jam pada setiap pengulangan jumlah kematian larva Aedes aegypti sudah mencapai $100 \%$. Sehingga pendataan waktu kontak 12 jam mengikuti hasil dari waktu kontak 8 jam. 
Hal ini menandakan ekstrak biji pepaya jenis California lebih efektif dibanding jenis Pepaya Bangkok terhadap kematian larva Aedes aegypti.

Perlakuan terhadap larva aedes dengan memaparkan biji pepaya jenis lokal atau cibinong mendapatkan hasil, terdapat perbedaan antara waktu kontak 1 jam dan 4 jam, 1 jam dan 8 jam, 1 jam dan 12 jam atau sebaliknya, sedangkan pada waktu kontak 4 jam dengan 8 jam, 4 jam dengan 12 jam, 8 jam dan 12 tidak terdapat perbedaan pengaruh terhadap kematian larva Aedes aegypti. Hal ini ditandai dengan data yang tidak varian atau dari hasil uji statistik tidak didapatkan angka p.value melainkan hanya titik.

Data yang tidak varian antara waktu kontak 4 jam, 8 jam dan 12 jam pada pemberian ekstrak biji pepaya jenis Lokal atau Cibinong disebabkan karena pada waktu kontak 4 jam pada setiap pengulangan jumlah kematian larva Aedes aegypti sudah mencapai $100 \%$. Sehingga pendataan waktu kontak 8 jam dan 12 jam mengikuti hasil dari waktu kontak 4 jam. Hal ini menandakan ekstrak biji pepaya jenis Lokal atau Cibinong lebih efektif dibanding jenis pepaya yang lainnya terhadap kematian larva Aedes aegypti karena jumlah kematian sudah $100 \%$ pada setiap pengulangan di waktu kontak 4 jam.

Pada tabel 3 dapat diketahui bahwa terdapat perbedaan yang siginifikan dari berbagai jenis ekstrak biji pepaya terhadap kematian larva Aedes aegypti. Antara jenis ekstrak Bangkok dan Cibinong didapatkan P.value $<\alpha$. Sehingga mengartikan bahwa ada perbedaan pengaruh yang signifikan antara jenis ekstrak Cibinong dan Bangkok terhadap kematian larva Aedes aegypti. Hal ini disebabkan jumlah kematian larva pada setiap jam memiliki selisih yang besar antara jenis ekstrak biji pepaya Cibinong dan Bangkok sehingga terdapat perbedaan yang signifikan. Sedangkan antara jenis ekstrak Bangkok dan California, jenis ekstrak Cibinong dan California memiliki p.value yang lebih besar dari $\alpha$. Sehingga mengartikan bahwa tidak ada perbedaan pengaruh yang signifikan antara jenis ekstrak Cibinong dan California serta Bangkok dan California terhadap kematian larva. Hal ini disebabkan jumlah kematian larva pada setiap jam memiliki selisih yang tidak terlalu besar pada jenis ekstrak biji pepaya Cibinong dan California serta Bangkok dan California.
$\mathrm{Hal}$ ini menandakan ekstrak Cibinong menjadi paling efektif terhadap kematian larva Aedes aegypti dikarenakan pada ekstrak biji pepaya jenis Cibinong mendapatkan jumlah kematian larva $100 \%$ pada setiap pengulangan di waktu kontak hanya 4 jam dari mulai dipaparkannya ekstrak pada larva Aedes aegypti.

Perbedaan karakteristik antara jenis biji pepaya beserta ekstraknya yang dapat diketahui selama proses penelitian adalah :

a. ekstrak biji Pepaya Cibinong yang dihasilkan lebih pekat dibanding ekstrak biji pepaya jenis yang lainnya.

b. Biji Pepaya Cibinong atau Lokal memiliki selaput yang membungkus biji tersebut sehingga dalam proses pengeringan pun biji Cibinong atau lokal memiliki waktu yang lebih lama dibanding jenis biji pepaya yang lainnya.

Kematian larva yang terpapar oleh ekstrak biji pepaya diduga disebabkan biji pepaya mengandung metabolit sekunder yang bersifat toksik. Metaboiit sekunder tersebut berupa senyawa kimia antara lain golongan senyawa alkaloid, flavonoid dan saponin.

Cara kerja alkaloid sebagai insektisida bervariasi tergantung dari struktur molekulnya tetapi banyak dilaporkan dalam menghambat enzim asetil kolinesterase atau jembatan natrium yang sangat berperan penting dalam sistem saraf. Selain itu alkaloid juga bertindak sebagai stomach poisoning atau racun perut. Bila senyawa tersebut masuk dalam tubuh larva maka alat pencernaannya akan menjadi rusak sehingga larva dapat mengalami kematian. (Ni'mah dkk, 2014)

Flavonoid memiliki efek larvasida karena menghambat sintesa asam nukleat (DNA) dan sebagai inhibitor kuat pernafasan. DNA diperlukan dalam sintesa atau pembentukan protein, yang sangat diperlukan oleh larva untuk proses perkembangan dan pertumbuhannya. Jika sintesa DNA terhambat maka sintesa protein akan terhambat pula sehingga perkembangan dan pertumbuhan larva tidak optimal bahkan bisa menyebabkan larva tersebut mati. (Ni'mah dkk, 2014)

Saponin memiliki aktivitas anti makan (antifeedant) dan menghambat pertumbuhan serta berinteraksi dengan membran kutikula larva yang kemudian akan merusak membran tersebut sehingga dapat menyebabkan kematian. (Ni'mah dkk, 2014) 
Senyawa saponin adalah jenis glikosida yang banyak ditemukan dalam tumbuhan. Saponin memiliki karakteristik berupa buih, sehingga ketika di reaksikan dengan air dan dikocok maka akan berbentuk buih yang dapat bertahan lama. Saponin mudah larut dalam air dan saponin memiliki rasa pahit menusuk dan menyebabkan iritasi pada selaput lendir. Saponin merupakan racun yang dapat menghancurkan butir darah atau hemolisis pada darah. (Hutari, Yusmidiarti, Mualim, 2014).

\section{KESIMPULAN}

Distribusi dan frekuensi rata-rata kematian larva Aedes aegypti pada ekstrak biji Pepaya Bangkok didapatkan rata-rata kematian sebesar 14.62, pada ekstrak biji Pepaya California didapatkan rata-rata kematian sebesar 18.56 , pada ekstrak biji Pepaya Cibinong didapatkan rata-rata kematian sebesar 22.12. Sedangkan untuk rata-rata kematian larva dalam 4 kali pengulangan yaitu pada waktu kontak 1 jam didapatkan rata-rata kematian sebesar 5.50. Pada waktu kontak 4 jam didapatkan rata-rata kematian sebesar 13.94. Pada waktu kontak 8 jam didapatkan rata-rata kematian sebesar 17.12. Pada waktu kontak 12 jam didapatkan rata-rata kematian sebesar 18.75. Terdapat perbedaan pengaruh antara setiap waktu kontak terhadap kematian larva Aedes aegypti yang diberi ekstrak biji Pepaya Bangkok, ekstrak biji Pepaya California, ekstrak biji Pepaya Cibinong. Terdapat perbedaan pengaruh jenis ekstrak biji pepaya yang bermakna antara jenis Pepaya Bangkok, jenis Pepaya California dan jenis Pepaya Lokal atau Cibinong dalam membunuh larva nyamuk Aedes aegypti instar III. Terdapat perbedaan waktu kontak yang bermakna antara waktu 1 jam, 4 jam, 8 jam dan 12 jam pengamatan dalam membunuh larva nyamuk Aedes aegypti instar III.

\section{DAFTAR PUSTAKA}

Dinas Kesehatan Provinsi Lampung, 2015. Profil Kesehatan Provinsi Lampung, Bandar Lampung.

Shinta, Sukowati, Supratman, 2013, Penggunaan Metode Survei Pupa Untuk Memprediksi Resiko Penularan Demam
Berdarah Dengue Di Lima Wilayah Endemis Di DKI Jakarta, Pusat Teknologi Intervensi kesehatan Masyarakat, Balitbangkes, Kemenkes RI.

Kardinan, A., 2003, Penggunaan Pestisida Nabati Sebagai Kearifan Lokal Dalam Pengendalian Hama Tanaman Menuju Sistem Pertanian Organik, Balai Penelitian Tanaman Obat dan Aromatik, Bogor.

Martini, Else Nina, 2016, Uji Kemampuan Ekstrak Biji Pepaya (Carica Papaya Linnaeus) Dalam Membunuh Larva Nyamuk Aedes Aegypti Tahun 2016, KTI, Poltekkes Tanjung Karang Jurusan Kesehatan Lingkungan.

Mehidyastuti, Erren, 2012, Pengaruh Pemberian Ekstrak Biji Pepaya (Carica Papaya Linnaeus) Sebagai Larvasida Terhadap Mortalitas Larva Aedes Aegypti, Thesis, Duta Wancana Christian University, Yogyakarta.

Fayzal, Muhammad Roy, 2016, Toksisitas Campuran Ekstrak Biji Pepaya (Carica papaya L.) Dan Biji Srikaya (annona squamosa L.) Terhadap Mortalitas Larva Nyamuk Aedes aegypti L., Fakultas Keguruan dan Ilmu Pendidikan Universitas Jember.

Suryabrata, Sumadi (BA., Drs., Ed.S., Ph.D), 2000, Metodologi Penelitian, Divisi Buku Perguruan Tinggi (UGM), PT. Raja Grafindo Persada, Jakarta.

World Health Organization, 1996, Operation manual on the application of insecticides for control of the mosquoto vectors of malaria and other disease, WHO Press.Geneva.

Ni'mah, dkk, 2014, Potensi Ekstrak Biji Duku (Lansium domerticum Coor) Terhadap Aedes Aegypti, Jurnal Loka Litbang P2B2, Baturaja, 6 halaman

Hutari, Yusmidiarti, Mualim, Efektivitas Ekstrak Biji Pepaya (Carica Papaya Linnaeus) Sebagai Larvasida Aedes Sp Instar III, Jurnal Kesehatan Lingkungan, Poltekkes Bengkulu, 9 halaman 